\title{
Hubungan Karakteristik Pasien dan Keluarga dengan Kepuasan Pelayanan di Puskesmas Cibeber, Kabupaten Cianjur
}

\section{Relationship Between Patient and Family Characteristics and Patient Satisfaction on Cibeber Community Health Service, Cianjur City}

\author{
Alib Birwin \\ Program Studi Kesehatan Masyarakat, Fakultas Ilmu-Ilmu Kesehatan \\ Universitas Muhammadiyah Prof. Dr. Hamka Jakarta \\ Jl. Limau II, Kebayoran Baru Jakarta Selatan 12130, \\ E-mail: alibbirwin@yahoo.com
}

\begin{abstract}
ABSTRAK
Kepuasan pasien terhadap pelayanan di Puskesmas dipengaruhi oleh banyak faktor. Tujuan penelitian ini adalah diketahuinya hubungan karakteristik keluarga dengan kepuasan pasien terhadap pelayanan pemeriksaan pada poli klinik umum, gigi, KIA/KB, dan apotik di Puskesmas Kecamatan Cibeber, Kabupaten Cianjur, Jawa Barat. Penelitian ini menggunakan disain studi cross sectional analitik. Populasi pada penelitian ini adalah seluruh pasien yang datang berobat kemasing-masing poliklinik dan apotik di Puskesmas Kecamatan Cibeber pada tahun 2011. Adapun sampel penelitian berjumlah 210 orang. Pengumpulan data dilaksanakan dengan wawancara kepada sampel terpilih menggunakan kuesioner. Pengolahan data dilakukan dengan komputer, dan análisis data dengan dua tahap yaitu análisis univariat dan análisis bivariat. Pada bagian Poliklinik Umum, pasien yang statusnya sebagai kepala keluarga lebih berpeluang 6 kali tidak puas pada pelayanannya (CI 95\%: 2,79-11,18). Sedangkan pasien laki-laki lebih berpeluang 11 kali tidak puas pada pelayanan Poliklinik gigi (CI 95\%: $(5.28-24.15)$. Pada pasien yang berstatus sebagai kepala keluarga berpeluang 9 kali tidak puas pada pelayanan Poliklinik KIA/KB (CI 95\%: 3.29 - 23.63) dan pada pasien yang berpenghasilan keluarga lebih dari Rp. 810.500/bulan lebih berpeluang 7 kali tidak puas pada pelayanan di Apotik (CI 95\%: 2.42 - 20.70). Penelitian ini merekomendasikan kepada puskesmas agar petugas kesehatan perlu memperbaiki kualitas pelayanan dengan cara meningkatkan keterampilan teknis dalam memeriksa pasien, meningkatkan pelayanan yang lebih ramah kepada pasien, serta tidak membiarkan pasien menunggu terlalu lama untuk mendapatkan pemeriksaan.
\end{abstract}

Kata Kunci: Karakteristik keluarga, pelayanan kesehatan, kepuasan pasien

\section{ABSTRACT}

Patient satisfaction in community healthcare is affected by many factors. The aim of this research was to determine the relationship between family characteristic and patient satisfaction upon healthcare service in General Clinic, Family Planning and Maternal and Child Care Clinic, Dental Clinic and Drugstore in Community Health Care in Cibeber, Cianjur, Jawa Barat. This research used cross sectional analytic design. Population in this research was all of patients that attend to Policlinics and Pharmacy unit. Research was conducted on 2011. Sampel in this research was 210 patients. Data was collected by doing an interview with sample using questionnaire. Data was processed by computer and data analysis using univariate and bivariate analytics. In general clinic, patient with status as head of family has a probability 6 times to dissatisfaction with the service $(C I 95 \%: 2,79-11,18)$. Men patients has a probability 11 times to not satisfy with the dental clinic service (CI 95\%: (5.28-24.15). Patient as a head family has probability 9 times to not satisfy with FP/MCC (CI 95\%: 3.29 - 23.63) and patient that has family income more than Rp. 810.500/month has a probability 7 times to not satisfy with Pharmacy service (CI 95\%: 2.42 20.70). This research suggested to staff of Community Healthcare to improve the quality of healthcare with improving their technical skill specially in examining the patient and improving education level, hospitality and decreasing waiting time for patient in getting examination.

Keywords: Family characteristics, health care, patient satisfaction 


\section{PENDAHULUAN}

Pelayanan kesehatan adalah suatu prosedur kompleks yang melibatkan pelayanan paripurna yang meliputi kegiatan preventif, promotif, kuratif, rehabilitatif. Pelayanan kesehatan merupakan suatu upaya yang diselenggarakan sendiri atau bersama dalam suatu organisasi untuk memelihara dan meningkatkan kesehatan, mencegah dan menyembuhkan penyakit, serta memulihkan kesehatan perseorangan, keluarga, kelompok ataupun masyarakat (Sianturi, 2015). Salah satu pelayanan kesehatan yang memegang peranan penting dalam penyelenggaraan kesehatan di Indonesia ialah Pusat Kesehatan Masyarakat (Puskesmas).

Kualitas pelayanan pemeriksaan kesehatan Puskesmas dapat diketahui dari penampilan profesional personil puskesmas, efisiensi dan efektifitas pelayanan serta kepuasan pasien. Kepuasan pasien adalah suatu tingkat perasaan pasien yang timbul sebagai akibat dari kinerja layanan kesehatan yang diperolehnya setelah pasien membandingkannya dengan apa yang diharapkannya (Suryawati, 2006). Kepuasan pasien ditentukan oleh keseluruhan pelayanan yaitu pelayanan dokter, pelayanan perawat, pelayanan makanan, obat-obatan, sarana dan peralatan, fasilitas dan lingkungan fisik Puskesmas serta pelayanan adminitrasi (Barsasella, 2012).

Kepuasan pasien terhadap pelayanan di Puskesmas dipengaruhi oleh banyak faktor yaitu pendekatan dan perilaku petugas terhadap perasaan pasien terutama saat pertama kali datang, mutu informasi yang diterima, prosedur perjanjian, waktu tunggu, fasilitas umum yang tersedia, dan perawatan yang diterima oleh pasien. Kepuasan pasien dapat berhubungan dengan karakteristik keluarga pasien yaitu gender, umur, status dalam keluarga, pendidikan, pekerjaan, penghasilan dan jumlah anggota keluarga (Direktorat Jenderal Bina Upaya Kesehatan, 2015).

Dalam rangka peningkatan kepuasan pasien terhadap pelayanan kesehatan di Puskesmas perlu adanya penelitian terhadap pelaksanaan pelayanan yang telah dilakukan selama ini. Penelitian ini dilakukan di Puskesmas Kecamatan Cibeber, Kabupaten Cianjur, Jawa Barat, di mana lebih spesifik dilakukan pada Poliklinik Umum, Poliklinik Gigi, Poliklinik
$\mathrm{KIA} / \mathrm{KB}$ dan Apotik.

Di masing-masing Poliklinik dan Apotik tersebut, peneliti sebelumnya telah melakukan survey pendahuluan terhadap 10 orang pengunjung. Kepada masing-masing pengunjung ditanyakan apa yang diharapkannya dan apa kenyataan yang dialaminya pada masing poliklinik dan apotik tersebut. Dari survey ini dapat disimpulkan bahwa sebagian dari mereka tidak puas terhadap pelayanan pemeriksaan. Seperti tersebut di atas banyak faktor yang berhubungan dengan kepuasan pasien terhadap pelayanan, antara karakteristik keluarga. Muncul pertanyaan bagaimana hubungan karakteristik keluarga yaitu gender, umur, status dalam keluarga, pendidikan, pekerjaan, penghasilan dan jumlah anggota keluarga dengan kepuasan pasien terhadap pelayanan pemeriksaan di Poliklinik umum, gigi, $\mathrm{KIA} / \mathrm{KB}$, dan farmasi. Tujuan penelitian ini adalah diketahuinya hubungan karakteristik keluarga dengan kepuasan pasien tehadap pelayanan pemeriksaan pada poliklinik umum, gigi, KIA/ KB, dan obat di Puskesmas Kecamatan Cibeber Kabupaten Cianjur Jawa Barat.

\section{SUBJEK DAN METODE}

Penelitian ini bersifat kuantitatif analitik dengan jenis desain penelitian studi cross sectional, dimana data dari variabel independen dan variabel dependen dikumpulkan pada waktu yang bersamaan. Populasi pada penelitian ini adalah seluruh pasien yang datang berobat pada masing-masing poliklinik dan apotik diPuskesmas Kecamatan Cibeber. Sampel penelitian adalah sebagian populasi di masing-masing poliklinik dan apotik, yang besar sampelnya dihitung menurut ketentuan Confidence level 95\% dan Kekuatan Uji 90\% sehingga jumlah sampel pada penelitian ini sejumlah 210 orang (Lapau, 2013).

Responden dalam penelitian ini yaitu pasien yang datang berobat ke masingmasing poliklinik dan apotik. Jenis data yang dikumpulkan adalah data primer dengan wawancara terstrukturur menggunakan instrumen kuesioner. Data dikumpulkan dari variabel dependen yaitu kepuasan pasien terhadap pelayanan pemeriksaan; di samping itu dikumpulkan data dari variabel independen yaitu gender, umur, status dalam keluarga, pendidikan kepala keluarga, pendidikan anggota keluarga, 
pekerjaan kepala keluarga, pekerjaan anggota keluarga, penghasilan keluarga, dan jumlah anggota keluarga.

Pengolahan data dilakukan dengan analisa univariat yakni untuk melihat distribusi frekuensi dari setiap variabel independen dan variabel dependen, sehingga dapat diketahui variasi dari masing-masing variabel serta analisa bivariat dilakukan untuk melihat kemaknaan hubungan antara variabel independen dan variabel dependen. Uji statistik yang digunakan adalah chi-square yakni melakukan analisa hubungan antara masing-masing variabel independen kategorik dengan satu variabel kategorik. Analisa ini bertujuan untuk menguji perbedaan antara dua proporsi dari masing-masing variabel independen sehingga diketahui ada/tidaknya hubungan yang bermakna secara statistik dengan mengunakan prevalence odds ratio (POR). Hubungan bermakna bila interval POR $>1$ atau hubungan terbalik bila $\mathrm{POR}<1$.

\section{HASIL}

Tabel 1 menunjukkan bahwa terdapat $70,9 \%$ responden adalah laki-laki, berumur kurang dari 30 tahun, dan bersatus kepala keluarga. Tabel 1 juga memperlihatkan bahwa $71,8 \%$ kepala keluarga berpendidikan SMA dan Perguruan Tinggi (PT), dan 52,4\% anggota keluarga berpendidikan SMA dan PT. Pada tabel distribusi variabel independen ini juga memperlihatkan bahwa $86,6 \%$ kepala keluarga bekerja sebagai buruh/tani/pedagang, sedangkan $50,8 \%$ anggota keluarga tidak bekerja/buruh/ tani/pedagang. Pada variabel independen penghasilan keluarga, terdapat $77,6 \%$ keluarga yang penghasilannya $<$ Rp. 810.000 per bulan, dan $72,4 \%$ responden yang jumlah anggota keluarganya 1 - 3 orang. Pada tabel 1 ini terlihat adanya variabel independen yang homogen, dimana salah satu kategorinya $<15 \%$ yaitu pada variabel pekerjaan kepala keluarga.

Tabel 1. Distribusi Variabel Independen Kepuasan Pasien Pengguna Layanan Pemeriksaan di Puskesmas Cibeber

\begin{tabular}{lcc}
\hline \multicolumn{1}{c}{ Karakteristik Responden } & Frekuensi & Persentase (\%) \\
\hline Jenis Kelamin & & 70.9 \\
Laki-laki & 149 & 29,1 \\
Perempuan & 61 & 70.9 \\
Umur & & 29,1 \\
$\leq 30$ tahun & 149 & \\
> 30 tahun & 61 & 22.4 \\
Penghasilan Keluarga/Bulan & & 77.6 \\
>Rp. 810.500 & 47 & \\
SRp. 810.500 & 163 & 72.4 \\
Jumlah Anggota Keluarga & & 27.6 \\
1-3 orang & 152 & \\
$4-6$ orang & 58 & 70.9 \\
Status dalam Keluarga & & 29,1 \\
Kepala keluarga & 149 & \\
Anggota Keluarga & 61 & 71,8 \\
Pendidikan Kepala Keluarga & & 28,2 \\
SMA dan PT & 107 & \\
SD dan SMP & 42 & 52.4 \\
Pendidikan Anggota Keluarga & & 47.6 \\
SMA dan PT & 32 & 86.6 \\
SD dan SMP & 29 & 13.4 \\
Pekerjaan Kepala Keluarga & & 50.8 \\
Buruh/tani dan pedagang & 129 & 49.2 \\
Swasta, PNS/TNI/POLRI & 20 & \\
Pekerjaan Anggota Keluarga & & \\
Tidak bekerja/Buruh/tani dan Pedagang & 31 & \\
Swasta/ PNS/TNI/POLRI & 30 & \\
\hline
\end{tabular}


$148 \sim$ Alib Birwin Hubungan Karakteristik Pasien dan Keluarga dengan Kepuasan Pelayanan di Puskesmas...

Tabel 2 menunjukkan variabel-variabel independen yakni gender, umur, status dalam keluarga, pendidikan kepala keluarga, dan jumlah anggota keluarga hubungannya dengan kepuasan pasien terhadap pelayanan pemeriksaan di Poliklinik Umum, Gigi, KIA/KB dan Apotik. Pasien laki-laki lebih berpeluang 5 kali tidak puas terhadap pelayanan pemeriksaan di poliklinik umum dibandingkan dengan pasien perempuan (CI 95\%: 2,52 - 9,97). Pasien yang berumur kurang dari 30 tahun lebih berpeluang 4 kali tidak puas terhadap pelayanan pemeriksaan di poli umum dibandingkan dengan pasien yang berumur lebih dari 30 tahun (CI 95\%: 2,07 - 7,99). Pasien yang statusnya sebagai kepala keluarga lebih berpeluang 6 kali tidak puas terhadap pelayanan pemeriksaan di poliklinik umum dibandingkan dengan pasien yang berstatus anggota keluarga (CI 95\%: 2,79 - 11,18). Pasien yang berstatus kepala keluarga dengan pendidikan SMA/ PT lebih berpeluang 4 kali tidak puas terhadap pelayanan pemeriksaan di poliklinik umum dibandingkan dengan pasien yang berstatus kepala keluarga dengan pendidikan SD/SMP (CI $95 \%$ : $1.68-8.55$ ). Pasien yang jumlah anggota keluarganya $1-3$ orang lebih berpeluang 3 kali tidak puas terhadap pelayanan pemeriksaan di poliklinik umum dibandingkan dengan pasien yang jumlah anggota keluarganya $4-6$ orang (CI $95 \%$ : $1.60-6,16)$.

Tabel 2. Distribusi Hubungan Variabel-variabel Independen Dengan Kepuasan Pasien Terhadap Pelayanan Pemeriksaan di Poliklinik Umum dan Gigi di Puskesmas Cibeber

\begin{tabular}{|c|c|c|c|c|c|c|}
\hline \multirow[t]{2}{*}{ Variabel } & \multicolumn{2}{|c|}{$\begin{array}{l}\text { Kepuasan Pasien } \\
\text { Poliklinik Umum }\end{array}$} & \multirow[t]{2}{*}{ OR 95\% CI } & \multicolumn{2}{|c|}{$\begin{array}{c}\text { Kepuasan Pasien } \\
\text { Poliklinik Gigi }\end{array}$} & \multirow[t]{2}{*}{ OR 95\% CI } \\
\hline & Tidak Puas & Puas & & Tidak Puas & Puas & \\
\hline \multicolumn{7}{|l|}{ Gender } \\
\hline Laki-laki & 110 & 39 & 5.00 & 117 & 32 & 11.21 \\
\hline Perempuan & 22 & 39 & $(2.52-9.97)^{*}$ & 15 & 46 & $(5.28-24.15)^{*}$ \\
\hline \multicolumn{7}{|l|}{ Umur } \\
\hline$\leq 30$ tahun & 108 & 41 & 4.06 & 54 & 7 & 7.02 \\
\hline$>30$ tahun & 24 & 37 & $(2.07-7.99)^{*}$ & 78 & 71 & $(2.84-18.12)^{*}$ \\
\hline \multicolumn{7}{|c|}{ Penghasilan Keluarga/bulan } \\
\hline$>$ Rp. 810.500 & 33 & 14 & 1.52 & 36 & 11 & 2.28 \\
\hline$\leq$ Rp. 810.500 & 99 & 64 & $(0.72-3.26)$ & 96 & 67 & $(1.03-5.15)^{*}$ \\
\hline \multicolumn{7}{|l|}{ Jumlah Anggota Keluarga } \\
\hline $1-3$ orang & 107 & 45 & 3.14 & 111 & 41 & 4.77 \\
\hline $4-6$ orang & 25 & 33 & $(1.60-6.16)^{*}$ & 21 & 37 & $(2.39-9.58) *$ \\
\hline \multicolumn{7}{|l|}{ Status dalam Keluarga } \\
\hline Kepala keluarga & 111 & 38 & 5.56 & 102 & 47 & 2.24 \\
\hline Anggota Keluarga & 21 & 40 & $(2.79-1.18)^{*}$ & 30 & 31 & $(1.17-4.32) *$ \\
\hline \multicolumn{7}{|c|}{ Pendidikan Kepala Keluarga } \\
\hline SMA dan PT & 77 & 30 & 3.77 & 82 & 25 & 3.61 \\
\hline SD dan SMP & 17 & 25 & $(1.68-8.55)^{*}$ & 20 & 22 & $(1.59-8.23) *$ \\
\hline \multicolumn{7}{|c|}{ Pendidikan Anggota Keluarga } \\
\hline SMA dan PT & 18 & 14 & 2.44 & 21 & 11 & 5.01 \\
\hline SD dan SMP & 10 & 19 & $(0.77-7.90)$ & 8 & 21 & $(1.48-17.55)^{*}$ \\
\hline \multicolumn{7}{|c|}{ Pekerjaan Kepala Keluarga } \\
\hline Buruh/tani dan pedagang & 61 & 68 & 1.10 & 58 & 71 & 1.23 \\
\hline Swasta, PNS/TNI/POLRI & 9 & 11 & $(0.39-3.12)$ & 8 & 12 & $(0.43-3.55)$ \\
\hline \multicolumn{7}{|c|}{ Pekerjaan anggota keluarga } \\
\hline Tidak bekerja/Buruh/Tani & 23 & 8 & 1.44 & 25 & 6 & 2.78 \\
\hline Swasta/ PNS/TNI/POLRI & 20 & 10 & $(0.42-5.01)$ & 18 & 12 & $(0.77-10.35)$ \\
\hline
\end{tabular}

*p-value: $<0.05$ 
Pada Poliklinik Gigi, Pasien laki-laki lebih berpeluang 11 kali tidak puas terhadap pelayanan pemeriksaan di poliklinik gigi dibandingkan dengan pasien perempuan (CI 95\%: (5.28 24.15); 2) Pasien yang berumur lebih dari 30 tahun lebih berpeluang 7 kali tidak puas terhadap pelayanan pemeriksaan di poli gigi dibandingkan denganpasien yang berumur kurang atau sama dengan 30 tahun (CI 95\%: 2,84 - 18,12). Pasien yang statusnya sebagai kepala keluarga lebih berpeluang2 kalitidak puas terhadap pelayanan pemeriksaan di poli gigi dibandingkan denganpasien yang berstatus anggota keluarga (CI $95 \%$ : 1,17 - 4,32). Pasien yang berstatus kepala keluarga dengan pendidikan SMA/PT lebih berpeluang 4 kali tidak puas terhadap pelayanan pemeriksaan di poliklinik gigi dibandingkan dengan pasien yang berstatus kepala keluarga dengan pendidikan SD/SMP (CI 95\%: 1.59 8,23 ). Pasien yang berstatus anggota keluarga dengan pendidikan SMA/PT lebih berpeluang 5 kali tidak puas terhadap pelayanan pemeriksaan di poli gigi dibandingkan denganpasien yang berstatus anggota keluarga dengan pendidikan SD/SMP (CI 95\%: 1,48 - 17,55). Pasien yang penghasilan keluarganya lebih dari 810.500 rupiah/bulan lebih berpeluang 2 kali tidak puas terhadap pelayanan pemeriksaan di poli gigi dibandingkan denganpasien yang penghasilan keluarganya kurang atau sama dengan 810.500 rupiah/bulan orang (CI 95\%: 1.03 - 5,15). Pasien yang jumlah anggota keluarganya $1-3$ orang lebih berpeluang 5 kali tidak puas terhadap pelayanan pemeriksaan di poli gigi dibandingkan denganpasien yang jumlah anggota keluarganya $4-6$ orang (CI 95\%: $2.39-9.58$ ).

Tabel 3. Distribusi Hubungan Variabel-variabel Independen Dengan Kepuasan Pasien Terhadap Pelayanan Pemeriksaan di Poliklinik KIA/KB dan Apotik di Puskesmas Cibeber

\begin{tabular}{|c|c|c|c|c|c|c|}
\hline \multirow[t]{2}{*}{ Variabel } & \multicolumn{2}{|c|}{$\begin{array}{c}\text { Kepuasan Pasien } \\
\text { Poliklinik KIA/KB }\end{array}$} & \multirow{2}{*}{ OR 95\% CI } & \multicolumn{2}{|c|}{$\begin{array}{c}\text { Kepuasan Pasien } \\
\text { Apotik }\end{array}$} & \multirow{2}{*}{ OR 95\% CI } \\
\hline & Tidak Puas & Puas & & Tidak Puas & Puas & \\
\hline \multicolumn{7}{|l|}{ Gender } \\
\hline Laki-laki & 111 & 38 & 5.56 & 103 & 46 & 2.47 \\
\hline Perempuan & 21 & 40 & $(2.79-11.18)^{*}$ & 29 & 32 & $(1.28-4.77)^{*}$ \\
\hline \multicolumn{7}{|l|}{ Umur } \\
\hline$\leq 30$ tahun & 47 & 14 & 2.53 & 94 & 55 & 1.03 \\
\hline$>30$ tahun & 85 & 64 & $(1.22-5.29) *$ & 38 & 23 & $(0.53-2.00)$ \\
\hline \multicolumn{7}{|c|}{ Penghasilan Keluarga/bulan } \\
\hline$>$ Rp. 810.500 & 40 & 7 & 4.41 & 42 & 5 & 6.81 \\
\hline$\leq$ Rp. 810.500 & 92 & 71 & $(1.71-11.51)^{*}$ & 90 & 73 & $(2.42-20.70)^{*}$ \\
\hline \multicolumn{7}{|l|}{ Jumlah Anggota Keluarga } \\
\hline $1-3$ orang & 112 & 40 & 5.32 & 101 & 51 & 1.45 \\
\hline $4-6$ orang & 20 & 38 & $(2.65-10.77) *$ & 37 & 27 & $(0.76-2.75)$ \\
\hline \multicolumn{7}{|l|}{ Status dalam Keluarga } \\
\hline Kepala keluarga & 55 & 6 & 8.57 & 75 & 74 & 0.66 \\
\hline Anggota Keluarga & 77 & 72 & $(3.29-23.63)^{*}$ & 37 & 24 & $(0.34-1.26)$ \\
\hline \multicolumn{7}{|c|}{ Pendidikan Kepala Keluarga } \\
\hline SMA dan PT & 52 & 55 & 0.95 & 67 & 40 & 1.14 \\
\hline SD dan SMP & 21 & 21 & $(0.44-2.05)$ & 25 & 17 & $(0.51-2.51)$ \\
\hline \multicolumn{7}{|c|}{ Pendidikan Anggota Keluarga } \\
\hline SMA dan PT & 24 & 8 & 6.67 & 19 & 13 & 3.84 \\
\hline SD dan SMP & 9 & 20 & $(1.91-24.35) *$ & 8 & 21 & $(1.16-13.12) *$ \\
\hline \multicolumn{7}{|c|}{ Pekerjaan Kepala Keluarga } \\
\hline Buruh/tani dan pedagang & 70 & 59 & 2.20 & 60 & 69 & 1.61 \\
\hline Swasta, PNS/TNI/POLRI & 7 & 13 & $(0.76-6.59)$ & 7 & 13 & $(0.55-4.83)$ \\
\hline \multicolumn{7}{|c|}{ Pekerjaan anggota keluarga } \\
\hline Tidak bekerja/Buruh/Tani & 23 & 8 & 2.52 & 24 & 7 & 2.62 \\
\hline Swasta/ PNS/TNI/POLRI & 16 & 14 & $(0.76-8.55)$ & 17 & 13 & $(0.76-9.26)$ \\
\hline
\end{tabular}


$150 \sim$ Alib Birwin Hubungan Karakteristik Pasien dan Keluarga dengan Kepuasan Pelayanan di Puskesmas...

Tabel 3 menjelaskan perbedaan kepuasan pasien pada Pada Poliklinik KIA/KB dan Apotik. Pasien laki-laki lebih berpeluang 6 kali tidak puas terhadap pelayanan pemeriksaan di poli KIA/ $\mathrm{KB}$ dibandingkan dengan pasien perempuan (CI $95 \%$ : 2.79 - 11.18). Pasien yang berumur lebih dari 30 tahun lebih berpeluang 3 kali tidak puas terhadap pelayanan pemeriksaan di poliklinik $\mathrm{KIA} / \mathrm{KB}$ dibandingkan denganpasien yang berumur kurang atau sama dengan 30 tahun (CI $95 \%$ : $1.22-5.29$ ). Pasien yang statusnya sebagai kepala keluarga lebih berpeluang 9 kalitidak puas terhadap pelayanan pemeriksaan di poliklinik $\mathrm{KIA} / \mathrm{KB}$ dibandingkan denganpasien yang berstatus anggota keluarga (CI 95\%: 3.29 23.63). Pasien yang berstatus anggota keluarga dengan pendidikan SMA/PT lebih berpeluang 7 kali tidak puas terhadap pelayanan pemeriksaan di poliklinik $\mathrm{KIA} / \mathrm{KB}$ dibandingkan dengan pasien yang berstatus anggota keluarga dengan pendidikan SD/SMP (CI 95\%: 1.91 - 24.35). Pasien yang penghasilan keluarganya lebih dari 810.500 rupiah/bulan lebih berpeluang 5 kalitidak puas terhadap pelayanan pemeriksaan di poliklinik KIA/KB dibandingkan dengan pasien yang penghasilan keluarganya kurang atau sama dengan $810.500 \mathrm{rupiah} / \mathrm{bulan}$ orang (CI $95 \%$ : 1.71 - 11.51). Pasien yang jumlah anggota keluarganya 1 - 3 orang lebih berpeluang 5 kali tidak puas terhadap pelayanan pemeriksaan di poliklinik $\mathrm{KIA} / \mathrm{KB}$ dibandingkan dengan pasien yang jumlah anggota keluarganya $4-6$ orang (CI 95\%: 2.65 - 10.77).

Pada pelayanan apotik, pasien laki-laki lebih berpeluang 3 kali tidak puas terhadap pelayanan pemeriksaan di apotik dibandingkan dengan pasien perempuan (CI 95\%: 1.28 - 4.77). Pasien yang berstatus anggota keluarga dengan pendidikan SMA/PT lebih berpeluang 4 kali tidak puas terhadap pelayanan pemeriksaan di apotik dibandingkan dengan pasien yang berstatus anggota keluarga dengan pendidikan SD/SMP (CI 95\%: 1.16 - 13.12). Pasien yang penghasilan keluarganya lebih dari 810.500 rupiah/bulan lebih berpeluang 7 kali tidak puas terhadap pelayanan pemeriksaan di apotik dibandingkan dengan pasien yang penghasilan keluarganya kurang atau sama dengan 810.500 rupiah/bulan orang (CI 95\%: 2.42 - 20.70).

\section{DISKUSI}

Hasil penelitian menunjukkan, pada Poliklinik Umum, terdapat hubungan yang bermakna secara statistik antara Gender, umur, jumlah anggota keluarga, status dalam keluarga, pendidikan kepala keluarga terhadap kepuasan pasien. Pada Poliklinik Gigi, terdapat hubungan yang bermakna secara statistik antara gender, umur, penghasilan keluarga/bulan, jumlah anggota keluarga, status dalam keluarga, pendidikan kepala keluarga, pendidikan anggota keluarga dengan kepuasan pasien. Terdapat hubungan yang bermakna secara statistik antara gender, umur, penghasilan keluarga/bulan, jumlah anggota keluarga, status dalam keluarga, pendidikan anggota keluarga dengan kepuasan pasien pada pasien Poliklinik KIA/KB. Terdapat hubungan yang bermakna secara statistik antara gender, penghasilan keluarga/bulan dan pendidikan anggota keluarga dengan kepuasan pasien pada pasien instalasi farmasi.

Puskesmas merupakan unit fungsionalyang berfungsi sebagai pusat pembangunan kesehatan, pusat pembinaan peran serta masyarakat dalam bidang kesehatan serta pusat pelayanan kesehatan tingkat pertama yang menyelenggarakan kegiatannya secara menyeluruh, terpadu, dan berkesinambungan pada suatu masyarakat yang bertempat tinggal dalam suatu wilayah tertentu. Salah satu unit pelayanan yang ada di puskesmas adalah pelayanan pemeriksaan kesehatan di poliklinik umum. Masyarakat yang datang berkunjung ke poliklinik umum biasanya datang dengan keluhan sakit yang ringan sampai berat. Sakit ringan misalnya penyakit-penyakit seperti keluhan pusing, demam, batuk pilek, atau diare, sedangkan sakit yang sudah berat biasanya dirujuk ke rumah sakit daerah setempat. (Mulyadi, 2013)

Tabel 2 menunjukkan variabel-variabel independen yang berhubungan dengan kepuasan pasien terhadap pelayanan pemeriksaan di Poliklinik Umum adalah gender, umur, status dalam keluarga, pendidikan kepala keluarga, dan jumlah anggota keluarga. Pasien laki-laki, pasien berumur kurang dari 30 tahun, pasien berstatus sebagai kepala keluarga, pasien yang berpendidikan tinggi, dan pasien yang jumlah anggota keluarga kecil adalah kelompok yang merasa tidak puas dengan pelayanan pemeriksaan 
kesehatan di poliklinik umum. Ketidak puasan kelompok tersebut kemungkinan disebabkan oleh kemampuan teknis tenaga kesehatan dalam menangani pasien, keramah tamahan dalam menangani pasien, serta waktu tunggu yang lama untuk diperiksa karena petugas datang terlambat, dan sebagainya.

Pada pelayananan kesehatan di Poliklinik Gigi, masih sering terjadi keluhan dari pasien/ keluarga berkaitan dengan kepuasan dimana hal ini berkaitan dengan sikap dan perilaku petugas antara lain: keterlambatan pelayanan dokter, dokter sulit ditemui, dokter yang kurang komunikatif dan informatif, sikap, perilaku, tutur kata, keacuhan, keramahan petugas, serta kemudahan mendapatkan informasi, dan komunikasi menduduki peringkat pertama terhadap persepsi kepuasan pasien/ keluarga pasien di puskesmas. (Lestari, 2009)

Tabel 2 menunjukkan bahwa pasien lakilaki, pasien yang berumur lebih dari 30 tahun, pasien yang statusnya sebagai kepala keluarga, pasien yang berstatus kepala keluarga dengan pendidikan tinggi, pasien yang berstatus anggota keluarga dengan pendidikan tinggi, pasien yang penghasilan keluarganya tinggi, dan pasien yang jumlah anggota keluarganya $1-3$ orang lebih berpeluang tidak puas terhadap pelayanan pemeriksaan di poliklinik gigi. Hasil ini mirip dengan ketidak puasan pasien yang diperiksa di poliklinik umum. Keterbatasan fasilitas alat dan bahan juga menjadi kendala bagi pasien untuk mendapatkan pelayanan kesehatan yang maksimal di poliklinik gigi. Oleh karena itu di masa depan kiranya pihak puskesmas perlu meningkatkan jumlah alat untuk pemeriksaan gigi serta pemeliharaan alat tersebut secara berkala.

Meningkatnya secara bermakna umur harapan hidup, menurunnya angka kematian ibu dan bayi, meningkatnya status gizi ibu dan anak, dan menurunnya angka fertilitas merupakan keberhasilan dari program kesehatan ibu dan anak serta program keluarga berencana yang telah dijalankan pemerintah selama selama ini. Upaya-upaya program $\mathrm{KIA} / \mathrm{KB}$ tersebut di tingkat puskesmas, dilaksanakan di unit pelayanan di poliklinik KIA/KB (Tietjen, 2010). Hasil penelitian pada tabel 3 menunjukkan bahwa pasien laki-laki, pasien yang berumur lebih dari 30 tahun, pasien yang statusnya sebagai kepala keluarga, pasien yang berstatus anggota keluarga dengan pendidikan tinggi, pasien yang penghasilan keluarganya tinggi, dan pasien yang jumlah anggota keluarganya kecil lebih berpeluang tidak puas terhadap pelayanan pemeriksaan di poliklinik KIA/KB. Faktor keterampilan petugas dan waktu tunggu yang lama untuk mendapatkan giliran diperiksa, merupakan faktor-faktor yang dapat memicu ketidak puasan pasien dan keluarganya terhadap pelayanan pemeriksaan di poliklinik KIA/KB. Kondisi ketidak puasan pasien ini tentunya dapat mengganggu target-target yang ingin dicapai oleh program $\mathrm{KIA} / \mathrm{KB}$. Oleh karena karena itu Puskesmas perlu lebih meningkatkan lagi kualitas layanan dan mempercepat waktu tunggu pasien di poliklinik pemeriksaan KIA/KB.

Apotik merupakan salah satu unit penting dalam pelayanan kesehatan di puskesmas. Dokter umum atau dokter gigi, setelah memeriksa dan mendiagnosa pasiennya, biasanya akan menuliskan resep obat terkait dengan penyakit pasien tersebut. Selanjutnya resep tersebut akan dibawa pasien ke apotik yang ada di puskesmas untuk mengambil obat sesuai dengan yang diresepkan oleh dokter. Setelah resep diserahkan kepada petugas apotik, pasien dipersilahkan menunggu sebelum mendapatkan obatnya. Pada situasi inilah pasien sering merasakan ketidak puasan terhadap pelayanan apotik karena waktu tunggu yang lama.(Suryawati, 2006)

Hasil penelitian pada tabel 3 menunjukkan bahwa pasien laki-laki, pasien yang berstatus anggota keluarga dengan pendidikan tinggi, dan pasien yang penghasilan keluarganya tinggi, tidak puas terhadap pelayanan di apotik. Waktu tunggu yang lama dan sering tidak tersedianya obat yang diresepkan oleh dokter menjadi alasan pasien tidak puas terhadap pelayanan di apotik puskesmas. Oleh karena itu perlu kiranya puskesmas lebih mempercepat waktu tunggu, sehingga pasien tidak perlu menunggu terlalu lama. Selain itu puskesmas perlu menambah jumlah stok obat yang tersedia, terutama obatobatan untuk penyakit-penyakit yang sering dialami masyarakat. 
$152 \sim$ Alib Birwin Hubungan Karakteristik Pasien dan Keluarga dengan Kepuasan Pelayanan di Puskesmas...

\section{KESIMPULAN}

Pasien laki-laki, pasien berumur kurang dari 30 tahun, pasien berstatus sebagai kepala keluarga, pasien yang berpendidikan tinggi, dan pasien yang jumlah anggota keluarga kecil adalah kelompok yang merasa tidak puas dengan pelayanan pemeriksaan kesehatan di poliklinik umum. pasien laki-laki, pasien yang berumur lebih dari 30 tahun, pasien yang statusnya sebagai kepala keluarga, pasien yang berstatus kepala keluarga dengan pendidikan tinggi, pasien yang berstatus anggota keluarga dengan pendidikan tinggi, pasien yang penghasilan keluarganya tinggi, dan pasien yang jumlah anggota keluarganya $1-3$ orang lebih berpeluang tidak puas terhadap pelayanan pemeriksaan di poliklinik gigi. pasien laki-laki, pasien yang berumur lebih dari 30 tahun, pasien yang statusnya sebagai kepala keluarga, pasien yang berstatus anggota keluarga dengan pendidikan tinggi, pasien yang penghasilan keluarganya tinggi, dan pasien yang jumlah anggota keluarganya kecil lebih berpeluang tidak puas terhadap pelayanan pemeriksaan di poliklinik $\mathrm{KIA} / \mathrm{KB}$. pasien laki-laki, pasien yang berstatus anggota keluarga dengan pendidikan tinggi, dan pasien yang penghasilan keluarganya tinggi, tidak puas terhadap pelayanan di apotik.

Petugas kesehatan di Puskesmas, khususnya yang berada di Poliklinik Umum, perlu memperbaiki kualitas pelayanan dengan cara meningkatkan keterampilan teknis dalam memeriksa pasien, misalnya dengan mengikuti pelatihan dan juga meningkatkan jenjang pendidikan, meningkatkan pelayanan yang lebih ramah kepada pasien, serta tidak membiarkan pasien menunggu terlalu lama untuk mendapatkan pemeriksaan.

\section{DAFTAR PUSTAKA}

Mulyadi, Dedi, Uus M Fadli, dan Fitriyani Cipta Kusuma Ningsih. (2013). Analisis Manajemen Mutu Pelayanan Kesehatan Pada Rumah Sakit Islam di Karawang. Jurnal Manajemen Vol 10 Nomor 3.

Barsasella, Diana.(2012). Sistem Informasi Kesehatan. Jakarta: Mitra Wacana Medika.

Direktorat Jenderal Bina Upaya Kesehatan. (2015). Pedoman Pengelolaan Peralatan Kesehatan di Fasilitas Pelayanan Kesehatan. Jakarta

Sianturi, Effendi. (2015). Organisasi dan Manajemen. Jakarta: Penerbit Buku Kedokteran

Lestari, Sri dan Emini. (2009). Pengendalian Infeksi Silang Pada Pelayanan Asuhan Keperawatan Gigi dan Mulut. Jakarta: Departemen Kesehatan Republik Indonesia, Poliklinikteknik Kesehatan Jakarta I.

Tietjen, Linda dan Debora B. (2010). Panduan Pencegahan Infeksi untuk Fasilitas Pelayanan Kesehatan dengan Sumber Daya Terbatas. Jakarta: Tridasa Printer

Lapau, Buchari. 2013. Metode Penelitian Kesehatan. Penerbit Yayasan Pustaka Obor Indonesia

Suryawati, Chriswardani. 2006. Penyusunan Indikator Kepuasan Pasien Rawat Inap Rumah Sakit Di Provinsi Jawa Tengah.Jurnal Manajemen Pelayanan Kesehatan, FKM UNDIP. 